\title{
Prevalence of pathological gambling in treatment-seeking addicted patients: An exploratory study with the South Oaks Gambling Screen
}

\author{
Javier Fernández-Montalvo*, José Javier López-Goñi y Alfonso Arteaga
}

Universidad Pública de Navarra

\begin{abstract}
Título: Prevalencia del juego patológico en pacientes adictos: Un estudio exploratorio con el South Oaks Gambling Screen.

Resumen: En este estudio se lleva a cabo un análisis de la prevalencia del juego patológico en 112 pacientes adictos (81 alcohólicos y 31 dependientes de la cocaína) que acuden en busca de tratamiento. Para ello, se utilizaron los criterios diagnósticos del DSM-IV-TR para el juego patológico y la versión española del Cuestionario de Juego Patológico de South Oaks (SOGS). Los resultados obtenidos mostraron que el 22,3\% de los pacientes drogodependientes estudiados presentaba un diagnóstico comórbido de ludopatía. Además, un 11,6\% adicional obtenía una puntuación en el SOGS indicadora de juego problemático. En suma, el $33,9 \%$ de la muestra presentaba síntomas de juego clínicamente significativos. La comparación entre los pacientes adictos con y sin ludopatía asociada mostró diferencias significativas en las variables relacionadas con el consumo de alcohol (evaluado mediante el EuropASI), los síntomas psicopatológicos (evaluados mediante el $S C L-90-R$ ) y algunas variables de personalidad (evaluadas mediante el $M C M I-I I)$. En todos los casos, las puntuaciones eran significativamente más altas en los pacientes ludópatas que en los que no tenían un problema de ludopatía asociado. Se comentan las implicaciones de este estudio para la práctica clínica y la investigación futura.

Palabras clave: juego patológico; adicción; alcoholismo; dependencia de la cocaína; comorbilidad.
\end{abstract}

\section{Introduction}

In recent years, there has been a growing interest in the study of comorbid disorders in addictive behaviours. This is probably due to the high rate of comorbidity observed in substance abusers and its large influence on therapeutic results. Efforts to improve the success rates of intervention programs for addicted patients have generated a clear interest in the study of variables that interfere with the results, or limit the reach, of these programs (Fernández-Montalvo et al., 2004).

Substance addiction is usually accompanied by a comorbid disorder (between 50\%-75\% of cases) (Casas, 1994). The most frequent comorbid disorders of substance addictions are personality disorders (Fernández-Montalvo \& Echeburúa, 2006; Fernández-Montalvo, Landa, López-Goñi \& Lorea, 2006; Lorea, Fernández-Montalvo, López-Goñi \& Landa, 2009), depression (mainly in females), anxiety (in both sexes) and abuse of other drugs (mainly in males) (Fernández-Montalvo, Lorea, López-Goñi \& Landa, 2008; Landa, Fernández-Montalvo, López-Goñi \& Lorea, 2006).

Some studies have shown the frequent coexistence of substance addiction and impulse control disorders. In a study by Lejoyeux, Feuche, Loi, Solomon \& Ades (1999), $38 \%$ of a sample of 79 alcoholics met the diagnostic criteria

* Dirección para correspondencia [Correspondence address]: Javier Fernández-Montalvo. Departamento de Psicología y Pedagogía. Universidad Pública de Navarra. Campus de Arrosadía. 31006 Pamplona (Spain). E-mail: fernandez.montalvo@unavarra.es
Abstract: In the current paper, the prevalence of pathological gambling in 112 treatment-seeking patients with substance addiction 81 alcoholics and 31 cocaine dependents) was estimated. The DSM-IV-TR diagnostic criteria for pathological gambling and the Spanish version of the South Oaks Gambling Screen (SOGS) were used. The results showed that $22.3 \%$ of substance-addicted patients had a comorbid diagnosis of pathological gambling. Furthermore, an additional $11.6 \%$ of the sample had relevant symptoms for problem gambling. In sum, $33.9 \%$ of the sample reported clinically significant gambling-related symptoms. From a socio-demographic point of view, all substance-addicted patients with gambling-related symptoms were men. A comparison between substance-addicted patients with and without pathological gambling showed significant differences in alcohol severity (assessed by the EuropASI), psychopathological symptoms (assessed by the $S C L-90-R$ ) and personality variables (assessed by the MCMI-II). In all cases, scores were significantly higher in gamblers than in non-gamblers. Finally, the implications of these results for further research and clinical practice are commented upon.

Key words: Pathological gambling; addiction; alcoholism; cocaine dependence; comorbidity.

for an impulse control disorder, with pathological gambling being the most prevalent. Furthermore, several studies have shown higher rates of pathological gambling among drug addicts (cf. Cunningham-Williams, Cottler, Compton, Spitznagel \& Ben-Abdallah, 2000; Langenbucher, Bavly, Lavouvie, Sanjuan \& Martin, 2001; Orford et al., 2003; Spunt, Dupont, Lesieur, Liberty \& Hunt, 1998; Steinberg, Kosten \& Rounsaville, 1992; Toneatto \& Brennan, 2002; Toneatto, Ferguson \& Brennan, 2003; Villas, Collakis, Magalhäes \& da Silveira, 2005), and have demonstrated its influence on therapeutic results (Ledgerwood \& Downey, 2002). Moreover, several studies with methadone patients have found rates of current pathological gambling ranging from $7 \%$ to 18\% (Feigelman, Kleinman, Lesieur, Millman \& Lesser, 1995; Ledgerwood \& Downey, 2002; Spunt, Lesieur, Liberty \& Hunt, 1996).

However, to date, only a few studies have been carried out on the prevalence of pathological gambling among drug abusers, most of them in the field of alcoholism. The results of these studies with alcoholics show a high rate of comorbidity between the two disorders, with rates of pathological gambling ranging from $8 \%$ to 33\% (Daghestani, Elenz \& Crayton, 1996; Fernández-Montalvo, Landa \& López-Goñi, 2005; Lesieur, Blume \& Zoppa, 1986; Rodriguez-Martos, 1989; Sanchez \& Rodriguez, 2006; Sellman Adamson, Robertson, Sullivan \& Coverdale, 2002; Welte, Barnes, Wieczorek \& Tidwell, 2004). The prevalence rate of pathological gambling in the general population is approximately 2\% (Becoña, 1996; Becoña, Míguez \& Vázquez, 2001; Bland, 
Newman, \& Orn Stebelsky 1993; Ladouceur, Jacques, Chevalier, Sevigny \& Hamel, 2005; Stucki \& Rihs-Middel, 2007; Volberg \& Abbott, 1994). This highlights the need to assess pathological gambling comorbidity among alcoholics seeking treatment in a clinical setting. In this regard, although not accepted by all researchers, it is important to note that the treatment of one addictive behaviour can generate or increase the involvement of the patient in another addiction to replace the treated one (substitute dependence) (Daghestani et al. 1996; Fernández-Montalvo et al., 2005).

Researchers have also found high rates of alcohol abuse and alcoholism among pathological gamblers (French, Maclean \& Ettner, 2008; Stewart \& Kushner, 2005). The studies carried out to date show rates ranging from $11 \%$ to $70 \%$, with wide variability among studies (Bland et al., 1993; Kausch, 2003; Martínez-Pina et al., 1991; Ramírez, McCormick, Russo \& Taber, 1983; Specker, Carlson, Edmonson, Johnson \& Marcotte, 1996).

The aims of this study were to carry out an accurate assessment of pathological gambling in a sample of addicted patients seeking outpatient treatment and to compare the severity of gambling dependence, as well as the psychopathological and personality variables, between addicts with and without pathological gambling. For the diagnosis of pathological gambling, DSM-IV-TR criteria (American Psychiatric Association, 2000) and the Spanish version (Echeburua, Baez, Fernández-Montalvo \& Páez, 1994) of the South Oaks Gambling Screen (SOGS) (Lesieur \& Blume, 1987) were used. This Spanish version has good psychometric properties. For the assessment of psychopathological and personality variables the SCL-90-R (Derogatis, 1992) and the MCMI-II (Millon, 1997) were used, because they are the more frequently used in other studies.

\section{Method}

\section{Participants}

The sample consisted of 112 substance-addicted patients (81 alcoholics and 31 cocaine dependents) who sought outpatient treatment at the "Proyecto Hombre Addiction Treatment Program" in Pamplona, Spain, during the period from November 2006 to August 2008. The assessment was made as a standardized protocol to all patients seeking for the treatment program. According to the current study's admission criteria, the patients had to a) meet the diagnostic criteria of alcohol or cocaine dependence according to DSM-IV-TR (APA, 2000); b) be between 18 and 65 years old; and c) give their informed consent to participate in the study. All eligible patients agreed to participate in the study.

Regarding the most significant demographic characteristics of the selected sample, the mean age was 43.9 years $(S D=11.6$, range $=18-65), 99(88.4 \%)$ were men and 13 (11.6\%) women. Regarding marital status, $39.3 \%(n=44)$ of the total sample was married, $36.6 \%(\mathrm{n}=41)$ single, $21.4 \%(\mathrm{n}=24)$ divorced and $2.7 \%(n=3)$ widower. Most of the sample was employed
$(68.8 \% ; \mathrm{n}=77)$ and with primary studies $(57.1 \% ; \mathrm{n}=64)$. The socioeconomic level was middle to lower-middle class.

With regard to substance addiction, mean alcohol consumption was frequent (6-7 days/week), with a mean of 216.7 grams $/$ day $(S D=123.6$, range $=50-640$ grams $/$ day $)$. Patients were alcohol dependent for nearly 12 years before seeking treatment $($ Mean $=11.8$, Median $=10.0, S D=6.8$; range $=1-30)$. Regarding cocaine abuse, mean consumption was frequent (5-6 days/week), with a mean of 6.7 grams/week (range: 0.5-42 gram/week). Patients were cocaine dependent for nearly 5 years before treatment $($ Mean $=5.1$, Median $=4.5, S D=3.5$; range $=1-17$ ).

\section{Assessment Measures}

Addiction variables

The EuropASI (Kokkevi \& Hartgers, 1995) is the European version of the Addiction Severity Index (ASI) (McLellan, Luborsky, O’Brein \& Woody, 1980). This interview assesses the need for treatment in the following six areas: a) general medical state; b) labour and economic situation; c) drug consumption (alcohol included); d) legal problems; e) family and social relationships; and f) psychological state. Scores range from 0 (no problem) to 9 (extreme problem) in each area and the cut-off point for each area is 4 . The Spanish version was used in this study (Bobes, Gónzález, Sáiz, \& Bousoño, 1996).

\section{Gambling variables}

The SOGS (Lesieur \& Blume, 1987; Spanish version by Echeburúa et al., 1994) is a screening questionnaire composed of 20 items that are related to gambling behaviour, loss of control, sources of money and emotions involved. In the Spanish version, this assessment tool has a test-retest reliability of .98 and an internal consistency of .94. The convergent validity with $D S M-I V$ criteria is .92 . The range is from 0 to 19 . A score higher than 4 (the cut-off point) serves to identify probable pathological gamblers.

\section{Psychopathological variables}

The Symptom Checklist-90-Revised (SCL-90-R) (Derogatis, 1992; Spanish version of González de Rivera, 2002) is a selfadministered general psychopathological assessment questionnaire. It comprises 90 items with 5 alternatives for each on a Likert-type scale, ranging from 0 (none) to 4 (very much). The aim of the questionnaire is to indicate a subject's symptoms of psychological disturbance. As it has been shown to be sensitive to therapeutic change, it may be used for either single or repeated assessments. The SCL-90-R consists of nine areas of primary symptoms: somatisation, obsessive-compulsive, interpersonal sensitivity, depression, anxiety, hostility, phobic anxiety, paranoid ideation and psychoticism. It also provides three indices that reflect the 
subject's overall level of severity. The Millon Clinical Multiaxial Inventory (MCMI-II) (Millon, 1997; Spanish version by Ávila, 2002) is a 175-item, true/false, self-report questionnaire. It was designed to identify clinical states and personality disorders similar to those contained in the DSM. The MCMI-II contains eight basic personality scales: 1) Schizoid-asocial; 2) Avoidant; 3) Dependent-submissive; 4) Histrionic-gregarious; 5) Narcissistic; 6) Antisocialaggressive; 7) Compulsive-conforming; and 8) Passiveaggressive. In addition to the basic personality patterns there are three pathological personality scales: Schizotypal (S), Borderline (B) and Paranoid (P). The MCMI-II also contains nine symptom scales: Anxiety, Somatoform, Hypomanic, Dysthymic, Alcohol abuse, Drug abuse, Psychotic thinking, Psychotic depression, and Psychotic delusion. However, in this study these additional Axis I clinical syndrome scales have not been taken into account because they are not relevant to the purposes of this research.

\section{Procedure}

Once the clinical sample was selected according to the previously described criteria, assessment of the sample was carried out in three sessions. In the first one, data related to socio-demographic characteristics and to drug consumption were collected. In the second session, the presence of psychopathological symptoms (with the SCL-90-R) and pathological gambling (with the SOGS) were assessed. Finally, in the third one, prevalence of personality disorders was assessed using the MCMI-II. According to the conservative criteria of Weltzler (1990) regarding the MCMI-II, a base rate score above 84 is considered to be significant.

\section{Results}

\section{Prevalence of pathological gambling}

Results showed that $22.3 \%$ (25 subjects) of the total sample met the diagnostic criteria of DSM-IV-TR (APA, 2000) for pathological gambling. This rate of comorbidity corresponded with results obtained with the SOGS.

The cut-off point in the Spanish version of the SOGS is four points. The mean $S O G S$ score for the entire addiction sample was $2.06(S D=3.3)$. However, from a clinical perspective, the number of addicted patients with a score above 4 was 25 subjects $(22.3 \%$ of the total sample). An additional $11.6 \%(n=13)$ endorsed two or three symptoms, which, in the Spanish version is considered an indication of a potential or preclinical gambling problem. These figures show that 33.9\% of this sample reported clinically significant gambling-related symptoms (22.3\% with pathological gambling and $11.6 \%$ with problem gambling).

The rate of pathological gambling in alcoholic patients was $23.4 \%$ (19 patients of the alcoholic sample), higher than that observed in cocaine addicted patients (6 cases; 19.3\%). However, there was no significant difference between the two samples $\left(X^{2}=0.22 ; p=.64\right)$.

\section{Comparison between groups}

From a socio-demographic point of view, all addicted patients with pathological gambling were men. No addicted women showed an associated gambling problem.

Table 1. Comparison between groups in addiction severity (EuropAsi).

\begin{tabular}{|c|c|c|c|c|}
\hline \multirow[t]{2}{*}{ Variables } & Total sample $(N=112)$ & With gambling $(N=25)$ & Without gambling $(N=87)$ & \multirow[t]{2}{*}{$t$} \\
\hline & Mean (SD) & Mean (SD) & Mean (SD) & \\
\hline Medical & $2.1 \quad(1.6)$ & $2.3 \quad(1.7)$ & $1.9 \quad(1.6)$ & 1.2 \\
\hline Job satisfaction & $2.5 \quad(1.8)$ & $3.1 \quad(2.1)$ & $2.3 \quad(1.8)$ & 1.8 \\
\hline Alcohol & $4.9 \quad(1.6)$ & $5.6 \quad(1.5)$ & $4.7 \quad(1.6)$ & $2.3^{*}$ \\
\hline Drugs & $2.4 \quad(2.2)$ & $3.1 \quad(2.5)$ & $2.2 \quad(2.1)$ & 1.3 \\
\hline Legal & $1.6 \quad(1.6)$ & $1.5 \quad(1.4)$ & $1.9 \quad(2.1)$ & 1.1 \\
\hline Family & $3.7 \quad(1.6)$ & $4.1 \quad(1.6)$ & $3.6 \quad(1.6)$ & 1.2 \\
\hline Psychological & $3.2 \quad(1.8)$ & $3.8 \quad(1.7)$ & $3.1 \quad(1.7)$ & 1.8 \\
\hline
\end{tabular}

$* p<.05$

Results of a comparison between patients with and without pathological gambling in addiction severity, as measured by the EuropASI, are presented in Table 1. As can be seen, the only statistical difference between groups was observed in the Alcohol severity area, which was significantly higher in addicts with gambling than in addicts without gambling. In the rest of variables of the EuropASI there were no statistical differences between gamblers and non-gamblers.
SCL-90-R results regarding psychopathology are shown in Table 2. Statistical differences between groups were observed in most of the 12 scales of the SCL-90-R. Except for Hostility scale, comparisons between both groups showed that scores of the gamblers were situated significantly above scores of the non-gambler addicts. 
Table 2. Comparison in the SCL-90-R (percentiles).

\begin{tabular}{|c|c|c|c|c|}
\hline \multirow{2}{*}{ Variables } & Total sample $(n=112)$ & With gambling $(n=25)$ & Without gambling $(n=87)$ & \multirow{2}{*}{$t$} \\
\hline & Mean (SD) & Mean (SD) & Mean (SD) & \\
\hline Global Symptoms Index & $69.0 \quad(29.5)$ & $84.3(21.2)$ & $64.6 \quad(30.1)$ & $3.7 * *$ \\
\hline Positive Symptoms Distress Index & $50.2(29.9)$ & $61.8 \quad(29.4)$ & $46.9 \quad(29.3)$ & $2.2^{*}$ \\
\hline Positive Symptoms Total & $72.9 \quad(27.7)$ & $86.1 \quad(22.0)$ & $69.1 \quad(28.1)$ & $3.2^{* *}$ \\
\hline Somatisation & $61.1 \quad(31.7)$ & $74.3 \quad(27.3)$ & $57.3 \quad(32.1)$ & $2.4^{*}$ \\
\hline Obsessive-compulsive & $62.8 \quad(32.7)$ & $76.4 \quad(29.2)$ & $58.9 \quad(32.7)$ & $2.4^{*}$ \\
\hline Interpersonal sensitivity & $67.5(29.7)$ & $86.0 \quad(20.1)$ & $62.1(29.9)$ & $4.5^{* * *}$ \\
\hline Depression & $65.2(30.2)$ & $82.6 \quad(20.5)$ & $60.2 \quad(30.7)$ & $4.2^{* * *}$ \\
\hline Anxiety & $61.1 \quad(32.8)$ & $74.7 \quad(23.3)$ & $57.2(34.2)$ & $2.9 * *$ \\
\hline Hostility & $52.7 \quad(32.5)$ & $61.3 \quad(28.2)$ & $50.2 \quad(33.3)$ & 1.5 \\
\hline Phobic anxiety & $54.4 \quad(35.6)$ & $72.5 \quad(33.8)$ & $49.2 \quad(34.6)$ & $3.0^{* *}$ \\
\hline Paranoid ideation & $65.8 \quad(30.2)$ & $81.9 \quad(23.1)$ & $61.2 \quad(30.5)$ & $3.7^{* *}$ \\
\hline Psychoticism & $71.2 \quad(29.4)$ & $81.4 \quad(29.6)$ & $68.3 \quad(28.9)$ & $2.0^{*}$ \\
\hline
\end{tabular}

$* p<.05 * * p<.01 \quad * * * p<.001$

Finally, from a quantitative point of view, statistical differences were observed in most of the scales of the MCMI-II (Table 3). With the exception of the compulsive scale the scores of gambler addicts were significantly higher than of nongamblers. However, from a qualitative point of view, there was only one statistical difference between groups in the rate of personality disorders (Table 4). Addicts with pathological gambling had a more prevalent rate of passive-aggressive personality disorder.

Table 3. Comparison in the MCMI-II

\begin{tabular}{|c|c|c|c|c|}
\hline \multirow[t]{2}{*}{ Variables } & Total sample $(N=112)$ & With gambling $(N=25)$ & Without gambling $(N=87)$ & \multirow[t]{2}{*}{$t$} \\
\hline & Mean (SD) & Mean (SD) & Mean (SD) & \\
\hline Schizoid & $60.3(33.1)$ & $64.1 \quad(24.9)$ & $59.3(35.1)$ & .6 \\
\hline Phobic & $49.8 \quad(28.1)$ & $65.1 \quad(23.5)$ & $45.5 \quad(27.8)$ & $3.5^{* * *}$ \\
\hline Dependence & $62.2 \quad(23.2)$ & $63.2 \quad(18.6)$ & $61.9 \quad(24.5)$ & .2 \\
\hline Histrionic & $52.8 \quad(20.2)$ & $56.1 \quad(21.5)$ & $52.1 \quad(19.9)$ & .9 \\
\hline Narcissistic & $51.1 \quad(24.3)$ & $52.1 \quad(23.1)$ & $50.8 \quad(24.8)$ & .2 \\
\hline Antisocial & $52.1 \quad(26.4)$ & $65.8 \quad(21.9)$ & $48.3 \quad(26.4)$ & $3.1 * *$ \\
\hline Aggressive-sadistic & $52.5 \quad(24.9)$ & $61.6 \quad(18.6)$ & $50.1 \quad(26.1)$ & $2.5^{*}$ \\
\hline Compulsive & $58.8 \quad(20.5)$ & $48.2 \quad(22.7)$ & $61.9 \quad(18.9)$ & $3.1^{* *}$ \\
\hline Passive-aggressive & $44.1 \quad(32.1)$ & $57.7 \quad(32.1)$ & $40.2 \quad(31.2)$ & $2.4^{*}$ \\
\hline Self-destructive & $49.6 \quad(23.4)$ & $60.9 \quad(17.1)$ & $46.4 \quad(24.1)$ & $3.4^{* * *}$ \\
\hline Schizotypal & $43.2 \quad(24.8)$ & $54.1 \quad(20.9)$ & $40.2 \quad(25.1)$ & $2.8^{* *}$ \\
\hline Borderline & $40.3 \quad(27.5)$ & $55.9 \quad(16.8)$ & $35.9 \quad(28.5)$ & $4.4^{* * *}$ \\
\hline Paranoid & $57.3 \quad(17.6)$ & $60.4 \quad(15.3)$ & $56.4 \quad(18.3)$ & 1.1 \\
\hline
\end{tabular}

Table 4. Personality disorders with the MCMI-II

\begin{tabular}{|c|c|c|c|c|}
\hline & Total sample $(N=112)$ & With gambling $(N=25)$ & Without gambling $(N=87)$ & $X^{2}$ \\
\hline & $(\%)$ & $(\%)$ & $(\%)$ & \\
\hline Schizoid & $12(10.7 \%)$ & $4 \quad(16 \%)$ & $8 \quad(9.2 \%)$ & 0.9 \\
\hline Phobic & $8 \quad(7.21 \%)$ & $3(12 \%)$ & $5 \quad(5.7 \%)$ & 1.1 \\
\hline Dependence & $15 \quad(13.4 \%)$ & $1 \quad(4 \%)$ & $14 \quad(16.1 \%)$ & 2.4 \\
\hline Histrionic & $2(1.8 \%)$ & $1 \quad(4 \%)$ & $1 \quad(1.1 \%)$ & 0.1 \\
\hline Narcissistic & $10 \quad(8.9 \%)$ & $2(8 \%)$ & $8 \quad(9.2 \%)$ & 0.1 \\
\hline Antisocial & $12 \quad(10.7 \%)$ & $5 \quad(20 \%)$ & $(8 \%)$ & 2.9 \\
\hline Aggressive-sadistic & $13(11.6 \%)$ & $3(12 \%)$ & $10 \quad(11.5 \%)$ & 0.1 \\
\hline Compulsive & $10 \quad(8.9 \%)$ & $1 \quad(4 \%)$ & $9 \quad(10.3 \%)$ & 0.9 \\
\hline Passive-aggressive & $14 \quad(12.5 \%)$ & $6 \quad(24 \%)$ & $8 \quad(9.2 \%)$ & $3.9^{*}$ \\
\hline Self-destructive & $6 \quad(5.4 \%)$ & $1 \quad(4 \%)$ & $5 \quad(5.7 \%)$ & 0.1 \\
\hline Schizotypal & $4 \quad(3.6 \%)$ & $1 \quad(4 \%)$ & $3(3.4 \%)$ & 0.1 \\
\hline Borderline & $5 \quad(4.5 \%)$ & $1 \quad(4 \%)$ & $4 \quad(4.6 \%)$ & 0.1 \\
\hline Paranoid & $5 \quad(4.5 \%)$ & $2 \quad(8 \%)$ & $3 \quad(3.4 \%)$ & 0.1 \\
\hline TOTAL $^{1}$ & $61(54.5 \%)$ & $14(56.0 \%)$ & $47(54.0 \%)$ & 0.0 \\
\hline
\end{tabular}

$* \mathrm{p}<.05$

${ }^{1}$ NOTE: The total number of people affected by personality disorders is less than the total sum of disorders because there are patients who presented more than one personality disorder. 


\section{Discussion}

This research contributes further evidence of an elevated prevalence rate of pathological gambling among addicted patients (Petry, 2007). As in previous studies (Cunningham-Williams et al., 2000; Daghestani et al., 1996; Fernández-Montalvo et al., 2005; Langenbucher et al., 2001; Lesieur et al., 1986; Orford et al., 2003; Rodríguez-Martos, 1989; Sellman et al., 2002; Welte et al., 2004), pathological gambling has a higher presence among addicted patients than in the general population (about $2 \%$ in epidemiologic studies).

In summary, results of this study show that $22.3 \%$ of the sample presented an associated problem of pathological gambling $(23.4 \%$ of alcoholics and $19.3 \%$ of cocaine addicts). All of them are men. This coincides with the results found in previous studies, which show that few women with a pathological gambling problem seek treatment in clinical settings (Echeburúa, González, Corral y Polo, 2011). Moreover, an additional $11.6 \%$ obtained a SOGS (Lesieur \& Blume, 1987) score that reflected the presence of problem gambling. These data show that $33.9 \%$ of this sample reported clinically significant gambling-related symptoms.

This figure is worrying, because most of the standard programs for clinical intervention with addicted patients do not include an assessment of pathological gambling. However, the results of this study show a need to take into account problems related to gambling, both in the clinical evaluation of addictions and in the development of specific treatment programs. Otherwise, the gambling problem could remain hidden or overlapped with the drug dependence and hinder therapeutic intervention.

Moreover, the risk of developing a substitute dependence in the treatment of the addictive behaviours should be considered. In these cases, the treatment of drug addiction may exacerbate the problems of pathological gambling presented by the patient or precipitate a relapse in drug consumption once abstinence is achieved. Therefore, some authors have suggested the possibility of a combined treatment for drug dependence and pathological gambling for this type of patient, with the aim of preventing the development of an

\section{References}

American Psychiatric Association (2000). Diagnostic and statistical manual of mental disorders $\left(4^{\text {th }} \mathrm{ed}\right.$. rev.). Washington, D.C. APA.

Ávila, A. (2002). Adaptación española del MCMI-II Inventario Clínico Multiaxial de Millon. Madrid: Tea Ediciones.

Becoña, E. (1996). Prevalence surveys of problem and pathological gambling in Europe: The cases of Germany, Holland and Spain. Journal of Gambling Studies, 12, 179-192.

Becoña, E., Míguez, M.C. y Vázquez, F.L. (2001). El juego problema en los estudiantes de enseñanza secundaria. Psicothema, 13, 551-556.

Bland, R.C., Newman, S.C., Orn, H. \& Stebelsky, G. (1993). Epidemiology of pathological gambling en Edmonton. Canadian Journal of Psychiatry, 38, 108112.

Bobes, J., González, M.P., Saiz, P.A. \& Bousoño, M. (1996). Índice Europeo de la Gravedad de la Adicción: EuropASI (versión española). Actas de la IV Reunión Interregional de Psiquiatría, 201-218. eventual substitute dependence (Daghestani et al. 1996; Fernández-Montalvo et al., 2005; Rodríguez-Martos, 1989).

On the other hand, the comparison between addicts with and without an associated problem of pathological gambling showed the existence of significant differences in psychopathological and personality variables. The results show an increased presence of psychopathological comorbidity in addicted patients who have an associated problem of gambling. These results agree with those obtained in previous studies (cf. Fernández-Montalvo et al. 2005; Langenbucher et al., 2001; Petry, 2000; Steinberg et al., 1992; Villas et al., 2005). All of them reflect a greater severity in addicted patients with pathological gambling.

Nevertheless, a limitation of this study is that the presented results were obtained with a relatively small sample (112 addicts). Therefore, it would be more appropriate to replicate this research with a wider sample of addicted patients, and with a bigger variety of drug abuse, not only alcohol and cocaine. Also, data from this study do not indicate the temporal relationship between the two addictions. In this sense, a logistic regression analysis could be suitable to test this kind of relationship, as well as to achieve a complete framework of the relationships between pathological gambling and other kind of variables: age, gender, kind of addiction (alcohol vs. cocaine), SCL-90-R and MCMI-II scores. In the study by Rodríguez-Martos (1989), 57\% of patients believed that the problem of alcoholism preceded the problem of pathological gambling. Also, Cho et al. (2002) found that alcohol problems preceded gambling in most dually diagnosed alcohol-dependent men. However, CunninghamWilliams et al. (2000) found that most pathological gamblers began using cigarettes, marijuana and alcohol prior to developing gambling problems, but pathological gambling often preceded dependence on other drugs, especially stimulants. This is an interesting question for future research.

Acknowledgments.- This study was supported by grant (code 2/2006) from the Health Department of Navarre Government (Spain). The authors would like to thank Fausto Yudego and the Proyecto Hombre Aldatu program staff for their help in assessing the clinical sample.

Casas, M. (1994). Psicopatología y alcoholismo. Barcelona. Citrán.

Cho, M.J., Hahm, B.J., Suh, T., Suh, G.H., Cho, S.J. \& Lee, C.K. (2002). Comorbid mental disorders among the patients with alcohol abuse and dependence in Korea. Journal of Korean Medical Science, 17, 236-241.

Cunningham-Williams, R.M., Cottler, L.B., Compton, W.M., Spitznagel, E.L. \& Ben-Abdallah, A. (2000). Problem gambling and comorbid psychiatric and substance use disorders among drug users recruited from drug treatment and community settings. Journal of Gambling Studies, 16, 347-376.

Daghestani, A.N., Elenz, E. \& Crayton, J.W. (1996). Pathological gambling in hospitalized substance abusing veterans. Journal of Clinical Psychiatry, 57, 360363.

Derogatis, L.R. (1992). The SCL-90-R. Clinical Psychometric Research. Baltimore. 
Echeburúa, E., Báez, C., Fernández-Montalvo, J. \& Páez, D. (1994). Cuestionario de Juego Patológico de South Oaks (SOGS): validación española. Análisis y Modificación de Conducta, 20, 769-791.

Echeburúa, E., González, I., Corral, P. y Polo, R. (2011). Clinical gender differences among adult pathological gamblers seeking treatment. Journal of Gambling Studies, 27, 215-227.

Feigelman, W., Kleinman, P.H., Lesieur, H.R., Millman, R.B. \& Lesser, M.L. (1995). Pathological gambling among methadone patients. Drug and Alcohol Dependence, 39, 75-81.

Fernández-Montalvo, J. \& Echeburúa, E. (2006). Juego patológico y trastornos de personalidad: un estudio piloto con el MCMI-II. Psicothema, 18, 453-458.

Fernández-Montalvo, J., Landa, N. \& López-Goñi, J.J. (2005). Prevalencia del juego patológico en el alcoholismo: un estudio exploratorio. Revista de Psicopatología y Psicología Clínica, 10, 125-134.

Fernández-Montalvo, J., Landa, N., López-Goñi, J.J. \& Lorea, I. (2006). Personality disorders in alcoholics: A comparative pilot study between the IPDE and the MCMI-II. Addictive Behaviors, 31, 1442-1448.

Fernández-Montalvo, J., López-Goñi, J.J., Landa, N., Illescas, C., Lorea, I. \& Zarzuela, A. (2004). Trastornos de personalidad y abandonos terapéuticos en pacientes adictos: resultados en una comunidad terapéutica. International Journal of Clinical and Health Psychology, 4, 271-283.

Fernández-Montalvo, J., Lorea, I., López-Goñi, J.J. \& Landa, N. (2008). Comorbilidad psicopatológica en la adicción a la cocaína: Resultados con el SCL-90-R. Behavioral Psychology/Psicología Conductual, 16, 275-288.

French, M.T., Maclean, J.C. \& Ettner, S.L. (2008). Drinkers and bettors: Investigating the complementarity of alcohol consumption and problem gambling. Drug and Alcohol Dependence, 96, 155-164.

González de Rivera, J.L. (2002). Versión española del SCL-90-R. Madrid. TEA.

Kausch, O. (2003). Patterns of substance abuse among treatment-seeking pathological gamblers. Journal of Substance Abuse Treatment, 25, 263-270.

Kokkevi, A. \& Hartgers, C. (1995). EuropASI: European adaptation of a multidimensional assessment instrument for drug and alcohol dependence. European Addiction Research, 1, 208-210.

Ladouceur, R., Jacques, C., Chevalier, S., Sevigny, S. \& Hamel, D. (2005). Prevalence of pathological gamblers in Québec in 2002. Canadian Journal of Psychiatry, 50, 451-456.

Landa, N., Fernández-Montalvo, J., López-Goñi, J.J. \& Lorea, I. (2006). Comorbilidad psicopatológica en el alcoholismo: un estudio descriptivo. International Journal of Clinical and Health Psychology, 6, 253-269.

Langenbucher, J., Bavly, L., Lavouvie, E., Sanjuan, P.M. \& Martin, C.S. (2001). Clinical features of pathological gambling in an addictions treatment cohort. Psychology of Addictive Behaviors, 15, 77-79.

Ledgerwood, D.M. \& Downey, K.K. (2002). Relationship between problem gambling and substance use in a methadone maintenance population. Addictive Behaviors, 27, 483-491.

Lejoyeux, M., Feuche, N., Loi, S., Solomon, J. \& Ades, J. (1999). Study of impulse control disorders among alcohol dependent patients. Journal of Clinical Psychiatry, 60, 302-305.

Lesieur, H.R. \& Blume, S.B. (1987). The South Oaks Gambling Screen (SOGS): A new instrument for the identification of pathological gamblers. American Journal of Psychiatry, 144, 1184-1188.

Lesieur, H.R., Blume, S.B. \& Zoppa, R.M. (1986). Alcoholism, drug abuse and gambling. Alcoholism: Clinical and Experimental Research, 10, 33-38.

Lorea, I., Fernández-Montalvo, J., López-Goñi, J.J. \& Landa, N. (2009). Adicción a la cocaína y trastornos de personalidad: un estudio con el MCMI-II. Adicciones, 21, 131-142.

Martínez-Pina, A., Guirao de Parga, J.L., Fusté, R., Serrat, X., Martín, M. \& Moreno, V. (1991). The Catalonia Survey: personality and intelligence structure in a sample of compulsive gamblers. Journal of Gambling Studies, 7, 275-299.
McLellan A.T., Luborsky, L., O’Brein, C.P. \& Woody, G.E. (1980). An improved evaluation instrument substance abuse patients: The Addiction Severity Index. Journal of Nervous and Mental Disorders, 168, 26-33.

Millon, T. (1997). Millon Clinical Multiaxial Inventory-II (MCMI-II). Minneapolis. National Computer Systems.

Orford, J., Boulay, S., Copello, A., Graves, N., Purser, B. \& Day, E. (2003). Gambling and problem gambling among clients, and staff attitudes, in alcohol and drug problems treatment service in the English Midlands. International Gambling Studies, 3, 171-181.

Petry, N. (2000). Psychiatric symptoms in problem gambling and non gambling substance abusers. American Journal on Addictions, 9, 163-171.

Petry, N. (2007). Gambling and substance use disorders: current status and future directions. American Journal on Addictions, 16, 1-9.

Ramírez, L.F., McCormick, R.A., Russo, A.M. \& Taber, J.L. (1983). Patterns of substance abuse in pathological gamblers undergoing treatment. Addictive Behaviors, 8, 425-428.

Rodríguez-Martos, A. (1989). Estudio piloto estimativo de la prevalencia de juego patológico entre los pacientes alcohólicos que acuden al Programa DROSS. Revista Española de Drogodependencias, 14, 265-275.

Sanchez, J.F. \& Rodriguez, J.J. (2006). Juego patológico asociado al alcoholismo: un estudio de comorbilidad. Anales de Psiquiatría, 22, 72-76.

Sellman, J.D., Adamson, S., Robertson, P., Sullivan, S. \& Coverdale, J. (2002). Gambling in mild-moderate alcohol-dependent outpatients. Substance Use and Misuse, 37, 199-213.

Specker, S.M., Carlson, G.A., Edmonson, K.M., Johnson, P.E. \& Marcotte, M. (1996). Psychopathology in pathological gamblers seeking treatment. Journal of Gambling Studies, 12, 67-81.

Spunt, B., Dupont, I., Lesieur, H.R., Liberty, H.J. \& Hunt, D. (1998). Pathological gambling and substance misuse: a review of the literature. Substance Use and Misuse, 33, 2535-2560.

Spunt, B., Lesieur, H.R., Liberty, H.J. \& Hunt, D. (1996). Pathological gamblers in methadone treatment: a comparison between men and women. Journal of Gambling Studies, 12, 431-449.

Steinberg, M.A., Kosten, T.A. \& Rounsaville, B.J. (1992). Cocaine abuse and pathological gambling. American Journal on Addictions, 1, 121-132.

Stewart, S.H. \& Kushner, M.G. (2005). Introduction to the special issue on "Relations between gambling and alcohol use". Journal of Gambling Studies, 21, 223-231.

Stucki, S. \& Rihs-Middel, M. (2007). Prevalence of adult problem and pathological gambling between 2000 and 2005: An update. Journal of Gambling Studies, 23, 245-257.

Toneatto, T. \& Brennan, J. (2002). Pathological gambling in treatmentseeking substance abusers. Addictive Behaviors, 27, 465-469.

Toneatto, T., Ferguson, D. \& Brennan, J. (2003). Effect of a New Casino on problem gambling in treatment-seeking substance abusers. Canadian Journal of Psychiatry, 48, 40-44.

Villas, S., Collakis, S.T., Magalhäes, M.P. \& da Silveira, D.X. (2005). Frequency of pathological gambling among substance abusers under treatment. Revista de Saúde Pública, 39, 1-6.

Volberg, R.A. \& Abbott, M.W. (1994). Lifetime prevalence estimates of pathological gambling in New Zealand. International Journal of Epidemiology, 23, 976-983.

Welte, J.W., Barnes, G.M., Wieczorek, W.F. \& Tidwell, M.C. (2004). Simultaneous drinking and gambling: a risk factor for pathological gambling. Substance Use and Misuse, 39, 1405-1422.

Weltzer, S. J. (1990). The Millon Clinical Multiaxial Inventory (MCMI): A review. Journal of Personality Assessment, 445-464.

(Article received: 24-05-2010, reviewed: 22-07-2011, accepted: 28-08-2011) 